\title{
Audiens Framing : Peluang Baru dalam Penelitian Audiens
}

\author{
Twediana Budi Hapsari \\ PhD Candidate from Department of Media Music Communication and Cultural \\ Studies, Faculty of Arts, Macquarie University, Sydney, NSW, Australia. \\ Dosen Komunikasi dan Penyiaran Islam, Fakultas Agama Islam, Universitas \\ Muhammadiyah Yogyakarta
}

\begin{abstract}
Abstrak
Studi tentang audiens adalah salah satu kajian penting dalam ilmu komunikasi. Kajian audiens ini berkembang seiring dengan perkembangan teknologi komunikasi itu sendiri, dari face to face communication hingga pemanfaatan teknologi digital dalam komunikasi. Audiens ini tidak bisa dipisahkan dari konteksnya sebagai anggota masyarakat dan lingkungan sosial. Oleh sebab itu dapat dipahami bahwa banyak faktor yang mempengaruhi proses audiens membingkai (frames) suatu isu dari media, tidak hanya berasal dari pengetahuan dan pengalaman pribadi yang dimiliki oleh individu audiens sendiri, namun juga faktor lain dari lingkungannya seperti pendapat dari kelompok rujukan dimana individu tersebut menjadi bagiannya juga penggunaan teknologi dalam mengakses media. Proses pembentukan bingkai isu dalam benak audiens disebut sebagai proses framing oleh audiens (audience framing).
\end{abstract}

Kata kunci : audiens, framing audiens, media

\begin{abstract}
The study of the audience is one of the key studies in communication science. Audience studies are growing along with the development of communication technology itself, from face to face communication to the use of digital technologies in communications. The audience can not be separated from its context as a member of society and social environment. Therefore it can be understood that many factors influence the process of framing the audience (frames) an issue of the media, not only from personal knowledge and experience possessed by individual audience itself, but also other factors of the environment such as the opinion of a reference group in which the individual also be part of technology use in accessing the media. The process of forming a frame issue in the minds of the audience referred to as the process of framing by the audience (audience framing).
\end{abstract}

Keywords: audience, audience framing, media

\section{Pendahuluan}

Secara umum audiens didefinisikan sebagai pengguna media. Namun dalam perkembangannya pemaknaan audiens berubah seiring dengan makin beragamnya pemanfaatan media untuk berbagai tujuan; tidak hanya untuk penyebaran informasi, tetapi juga kampanye politik dan pemasaran produk. Virginia Nightingale memetakan empat posisi audiens berdasarkan hubungannya dengan media, yaitu publik, pasar, komunitas dan fans (Nightingale, 2004). Audiens dipandang sebagai publik ketika 
komunikator melihat audiens memiliki beragam kepentingan politik. Sedangkan audiens dipandang sebagai target pasar ketika mereka menjadi sasaran iklan produk yang ada di media. Ketika audiens dilihat sebagai bagian dari budaya yang mengekspresikan identitasnya melalui teks media, maka mereka disebut sebagai komunitas. Terakhir, kata fans berasal dari asal kata ,fanatik' yang artinya seseorang yang sikap dan perilakunya sangat dipengaruhi oleh orang lain yang menjadi idolanya (Sullivan, 2013).

Jika dirunut dari sejarah perkembangan teknologi komunikasi, Abercrombie \& Longhurst (1998) membagi audiens dalam dalam tiga tahap: simple audience, mass audience dan diffusion audience. Simple audience atau audience sederhana adalah audience dalam komunikasi langsung (face to face communication) seperti audience dalam pertunjukan konser atau opera. Kajian ini paling banyak dilakukan pada saat teknologi media belum banyak digunakan masyarakat pada abad 19. Mass audience ditujukan pada audience yang membaca surat kabar, mendengarkan radio dan menonton televisi. Dalam perkembangan beragam teknologi media yang semakin pesat saat ini, audience cenderung mengakses lebih dari satu media sekaligus dalam satu waktu yang disebut sebagai audience yang tersebar (diffusion audience). Misalnya seseorang membaca surat kabar sambil menonton siaran berita di televisi, atau browsing internet bersamaan dengan mendengarkan radio.

Tradisi penelitian tentang audiens mulai berkembang sejak tahun 1920-an, ketika media radio diciptakan dan mulai digunakan secara massal. Beberapa ilmuwan mencoba mengklasifikasikan tradisi penelitian audiens ini, seperti Jensen \& Rosengren (1990), Webster
(1998) dan Marie Gillespie (2005). Jensen \& Rosengren (1990) mengklasifikasikan tradisi penelitian audiens menjadi lima, yaitu: penelitian efek media, uses $\mathcal{E}$ gratifications, penelitian yang mengkritisi text media, cultural studies dan reception analysis.

Di sisi lain, James G Webster (1998) berpendapat bahwa relasi antara media-audience bisa dilihat dalam tiga model dasar, yaitu audiens sebagai tujuan (audience as outcome), audiens sebagai massa (audience as mass) dan audiens sebagai agen (audience as agen) (Webster, 1998). Pada model pertama, media memiliki peran kuat dalam mempengaruhi audiens, sehingga termasuk dalam model ini adalah teori efek, propaganda, perubahan sikap dan film theory. Pada model kedua, audiens dilihat sebagai kumpulan banyak orang, anonim,dan tersebar luas dan tidak saling kenal satu sama lain. Studi yang termasuk dalam kategori ini di antaranya rating dan komoditas audiens, perilaku massa dan media events. Model terakhir, audiens sebagai agen, melihat audiens memiliki kebebasan memilih media, juga menginterpretasikan isi media berdasarkan pengetahuan dan pengalamannya sendiri(Sullivan, 2013).

Selanjutnya, Marie Gillespie (2005) menyederhanakan pembagian tradisi relasi media-audiens ini menjadi dua, yaitu tradisi efek media (media effect tradition) dan tradisi penggunaan serta interpretasi media (media use and interpretation). Penelitian dalam tradisi pertama menekankan pada efek media terhadap audience. Dalam hal ini audience dianggap pasif (passive audience). Sedangkan penelitian pada tradisi kedua menekankan peran aktif audience (active audience) dalam memilih dan mengkonsumsi isi media serta 
aktif dalam menginterpretasi isi media (Gillespie, 2005).

Ditinjau dari jenis tradisi penelitian di atas, penelitian audiens framing termasuk dalam tradisi penelitian efek, yaitu efek dari media frames (Scheufele, 1999). Dennis McQuail membagi penelitian efek media ini menjadi empat tahap, yaitu diawal abad 20 hingga tahun 1930-an, tahun 1930-an hingga akhir 1960-an, dekade 1970-an, dan awal 1980-an hingga saat ini (McQuail, 1994). Pada tahap pertama, yaitu pada masa Perang Dunia I, penelitian didominasi pada strategi propaganda perang yang mengakibatkan munculnya ketakutan terhadap kuatnya pengaruh media terhadap perilaku audiens. Tahap kedua, penelitian cenderung kebalikan dari tahap pertama, yaitu perubahan perilaku publik tidak disebabkan oleh pengaruh media melainkan oleh pengaruh orang lain. Klapper (1960) menyimpulkan dalam penelitiannya bahwa pengaruh perilaku memilih seseorang dalam pemilu tidak dipengaruhi oleh kampanye melalui media, tetapi oleh pengaruh orang-orang di sekelilingnya (Klapper, 1960). Tahap ketiga dimulai pada awal tahun 1970an, ketika fokus penelitian tidak lagi pada perubahan perilaku audiens, namun pada efek kognisi atau pengetahuan audiens. Tahap keempat adalah penelitian yang didominasi oleh term 'konstruksi sosial'. Pada tahap ini hubungan antara mediaaudiens bercampur antara efek kuat dan terbatas dari media. Pada satu sisi, media memilikikekuatandalammengkonstruksi realitas yang dituangkan dalam teks media. Namun di sisi lain, audiens juga tidak semata-mata 'menerima' teks media sebagaimana adanya. Audiens juga akan 'mengkonstruk' makna berdasarkan tidak hanya apa yang ada dalam teks media, namun juga mempertimbangkan nilai, keyakinan dan pengalaman yang dia miliki serta pengetahuan yang dia peroleh dari kelompok referensi (Scheufele, 1999).

Audiens framing sebagai ranah kajian efek merupakan pengembangan dari kajian teori framing itu sendiri. Di awal penelitian tentang framing tahun 1980-an, fokus penelitian masih bertumpu pada media framing dalam kajian komunikasi politik dan opini publik. Hingga pada akhir tahun 1990-an Dietram Scheufele melihat teori framing dalam pendekatan yang lebih komprehensif, dengan tidak hanya menjelaskan teori framing dari dua dimensi- media frames dan audiens frames - namun juga menjelaskan bagaimana kedua dimensi tersebut berinteraksi sebagai variabel dependen dan independen (Scheufele, 1999). Bab ini akan menjelaskan tentang audiens framing, beberapa penelitian tentang audiens framing, serta beberapa model proses framing di media dan audiens. Selain itu bab ini juga akan menjelaskan tentang faktor-faktor yang mempengaruhi proses terbentuknya frames di benak audiens.

\section{Teori Framing}

Studi tentang framing dalam media dan komunikasi tiga dekade terakhir ini menjadi tren di antara ilmuwan sosial. Menurut SSCI index dibawah kategori 'ilmu komunikasi', jumlah artikel yang memuat kata 'frame' atau 'framing' bertambah secara drastis. Pada tahun 1977 sampai 1991 jumlah artikel yang terindex kurang dari 10, kemudian meningkat menjadi 20 artikel pada tahun 1995 dan mencapai puncaknya pada tahun 2009 sejumlah 90 artikel (R. V. L. v. Zoonen, 2011). Konsep framing telah digunakan dalam bidang sosiologi sejak pertengahan th 1950 oleh Bateson, dan pertama kali 
dipopulerkan dalam studi komunikasi oleh Goffman pada tahun 1974. Setelah artikel Entman berjudul 'Framing as a Fracture Paradigm' yang dipublikasikan pada tahun 1993, penggunaan term 'frame' atau 'framing' menjadi semakin luas sejak saat itu (Kitzinger, 2007). Framing berarti proses menseleksi dan memberi perhatian lebih pada suatu bagian peristiwa. Istilah frame dan framing telah digunakan dalam beragam bidang seperti sosiologi, politik, linguistik, psikologi dan seni murni (Kitzinger, 2007). Dalam bidang Sosiologi, Erving Goffman (1974) mendefinisikan frame sebagai 'schemata of interpretation' atau 'bagian yang mendapat perhatian lebih untuk diinterpretasi'. Dalam proses ini individu menentukan, mempersepsi, mengidentifikasi dan memberi label pada suatu peristiwa atau informasi(Kosicki, 1993). Dalam bidang Psikologi, istilah framing berhubungan dengan proses kognitif individu dalam memproses informasi. Sedangkan di bidang politik, Entman mendefinisikan framing sebagai 'opini publik' dimana dalam proses demokrasi, framing ini dikontrol oleh elit politik (Entman, 1993).

Proses framing pada intinya adalah menseleksi dan menonjolkan suatu fakta. Robert Entman (1993) mendefinisikan framing adalah menseleksi beberapa aspek dari realitas yang ada dan membuatnya menjadi lebih menonjol ketika dikomunikasikan kedalam teks (Entman, 1993). Tahapan dalam proses framing adalah: menentukan masalah, mendiagnosa sebab timbulnya masalah, membuat penilaian moral dan menawarkan solusi terhadap masalah tersebut. Proses framing ini terjadi pada unsur-unsur komunikasi; seperti komunikator, teks, audiens dan budaya. Komunikator yang memutuskan framing dari suatu issues. Issue tersebut kemudian dituangkan ke dalam teks berita, yang menampilkan atau tidak menampilkan suatu fakta, diberi istilah, imej stereotipe, sumber informasi dan juga kalimatkalimat yang dibuat untuk menonjolkan fakta atau penilaian terhadap suatu issue. Frame yang ada dalam media teks kemudian menggiring pemikiran dan kesimpulan audiens terhadap suatu issue, atau bahkan tidak merefleksikan frame di dalam teks atau frame yang diinginkan komunikator. Terakhir adalah konteks latar belakang budaya yang mempengaruhi komunikator dan audiens dalam melakukan proses framing (Entman, 1993).

Dari penjelasan diatas tampak bahwa proses framing terjadi tidak hanya pada komunikator, tapi juga pada teks, audiens dan budaya, karena memahami framing berarti memahami bagaimana proses mempresentasikan suatu berita serta bagaimana memahaminya. Oleh sebab itu dalam framing dikenal adanya dua konsep: media framing atau framing yang dibuat di media dan audience framing atau framing yang dilakukan oleh audiens. Secara umum, proses pemaknaan yang terjadi pada media framing dan audience framing sejalan dengan yang dijelaskan oleh Hall dalam model encode/decode (Hall, 1980). Komunikator atau pengelola media meencode pesan yang akan dimuat di media, dengan menseleksi dan menekankan titik berat pada fakta yang sekiranya akan menarik perhatian audiens. Audiens mengakses media dan me-decode teks yang telah dikemas tadi sesuai dengan latar belakang pengetahuan, nilai, budaya juga referensi dari orang-orang yang berpengaruh terhadap audiens. Sehingga isi teks media bisa mengandung banyak makna atau polisemy, tergantung siapa yang memaknainya. 


\section{Perkembangan Studi Audience Framing}

Studi mengenai audience framing berawal dari analisis framing di media meliputi proses terbentuknya frame media dan faktor-faktor yang mempengaruhinya. Beberapa ilmuwan studi media meneliti konstruksi sosial dalam pemberitaan media; seperti yang dilakukan Gitlin (1980) yang meneliti proses framing dimedia AmerikaSerikat terhadap gerakan mahasiswa tahun 1960, atau Van Zoonen (1992) dan Tuchman (1978) yang meneliti konstruksi media terhadap gerakan pembebasan perempuan di Belanda dan Amerika sekitar tahun 1970-an (Gitlin, 1980; Tuchman, 1978; V. Zoonen, 1992).Selain itu, Pan \& Kosicki (1993) juga mengenalkan metode análisis teks media dari empat dimensi struktural yaitu struktur sintaksis, struktur skrip, struktur tema dan struktur retorika (Kosicki, 1993). Penelitian-penelitian tersebut tidak hanya melihat bagaimana suatu peristiwa di'konstruk' dan diframing dalam media teks, namun juga melihat proses produksi media seperti bagaimana kerja para jurnalis menentukan faktafakta yang lebih ditonjolkan, keterbatasan ruang dan waktu dalam media, juga mempertimbangkan kepentingan elit politik dan kebutuhan finansial untuk biaya operasional media. Atau dengan kata lain proses pembentukan framing media merupakan hasil interaksi sosial antara elit politik dan aktor media serta lingkungan sosial (R. V. L. v. Zoonen, 2011).

Penelitian tentang framing dan pengaruhnya terhadap audiens mulai mendapat perhatian dalam kajian media frames dan pembentukan opini publik. Gamson (1992) melihat adanya kaitan antara gerakan sosial, liputan media dan pembicaraan keseharian masyarakat.
Gamson juga melihat adanya pengaruh frame dominan di media yang bersumber dari pejabat pemerintah dan pelaku ekonomi dengan frame kritis yang dikembangkan oleh audiens dalam percakapan sehari-hari. Gamson menyimpulkan bahwa media frame akan berpengaruh kuat ke audiens ketika mereka tidak memiliki pengalaman dan pengetahuan yang cukup terkait dengan issue yang diangkat dalam media. Sebaliknya, media frame tidak akan memiliki peran yang berarti ketika audiens memiliki pengetahuan dan pengalaman cukup tentang suatu isu dan bertentangan dengan isi media, dalam hal ini audiens lebih mempercayai isu yang beredar dalam diskusi publik dibanding dengan frame media.

Penelitian pengaruh media terhadap gerakan sosial juga dieksplorasi oleh David Snow dkk (1986) yang melihat adanya ketimpangan dalam kajian-kajian social movement pada waktu itu tanpa pengaruh isi media. Menurut Snow, dua pendekatan umum yang dipakai dalam mengkaji gerakan sosial yaitu perspektif psiko-fungsional (psychofunctional)dan perspektif sumber mobilisasi (the resource mobilization perspective) tidak memperhatikan proses intepretasi ketidakpuasan (grievance intepretation) yang didapat diantaranya melalui media (David A Snow, E Burke Rochford, 1986).

Terkait dengan hal tersebut, Snow dkk mengenalkan konsep frame alignment, yaitu deretan frame-frame yang menjadi inspirasi gerakan sosial tersebut. Proses frame alignmentmerupakan proses penting dalam gerakan partisipasi individu dalam gerakan sosial, meliputi empat proses, yaitu: frame bridging, frame amplification, frame extensión dan frame transformation. Frame bridging adalah proses menghubungkan dua ideologi 
atau lebih yang tidak berhubungan sebelumnya, namun memiliki perhatian yang sama pada satu isu, yang pada akhirnya menggerakkan individu maupun organisasi untuk melakukan social movement bersama. Frame amplification adalah pemantapan frame dengan melakukan klarifikasi terhadap isu dikaitkan dengan nilai dan kepercayaan tiap individu dan kelompok yang terlibat. Frame extention adalah upaya memperluas isu yang diframe sebelumnya, untuk semakin menguatkan alasan gerakan sosial yang dimaksud. Terakhir, frame transformation adalah proses merubah frame yang sudah kuat pada proses sebelumnya menjadi bentuk frame baru yang lebih menarik dan memberikan alternatif kepada participan untuk berbuat sesuatu.

Sejalan dengan penelitian Gamson dan Snow di atas, lebih lanjut David Morley dalam penelitiannya berjudul Nationwide Audience (1980) menemukan kaitan antara ideologi dan pengetahuan yang telah dimiliki audiens sebelumnya akan mempengaruhi cara audiens mengintepretasikan isi teks media dan menghasilkan pemaknaan yang berbeda pula. Morley mengklasifikasikan tiga kemungkinan cara audiens membaca isi media yaitu: preferred Reading, negotiated Reading dan alternative/oppositional Reading. Preferred reading adalah audiens yang menerima semua isi teks media tanpa mempertanyakan lebih lanjut. Kebalikannya, audiens yang menolak isi teks media disebut Alternative/oppositional reading. Sedangkan negotiated reading adalah audiens yang menegosiasikan makna dalam teks media, dia hanya menerima yang menurutnya sesuai dengan nilai, pengetahuan dan pengalaman yang telah dimiliki sebelumnya.
Fokus penelitian framing kemudian berkembang pada efek framing, yaitu melihat pengaruh framing media terhadap audiens. Druckman (2001) dan Vreese (2012) memiliki pendapat yang berbeda dalam mengkategorikan studi efek framing ini. James $\mathrm{N}$ Druckman dalam artikelnya berjudul On the Limits of Framing Effects: Who Can Frame? menitikberatkan klasifikasinya berdasarkan isi frame media yang bisa mempengaruhi opini audiens; yaitu bagaimana frame yang berbeda di media bisa mempengaruhi opini audiens dan bagaimana frame yang berbeda di media melahirkan opini yang berbeda pula di benak audiens (Druckman, 2001). Di sisi lain, Vreese membedakan efek framing media ini pada teknis pemuatan frame di media; yaitu berapa lama suatu efek framing bertahan dibenak audiens dan apa yang terjadi jika suatu frame dimuat di media berulang-ulang (Vreese, 2012).

Beberapa penelitian efek framing mengeksplorasi perbedaan frames dalam media dan efeknya pada audiens. Penelitian Iyengar (1991) tentang efek berita politik di televisi terhadap atribusi publik merupakan penelitian awal di bidang efek framing. Iyengar menemukan adanya perbedaan efek framing pada cara media membingkai berita dalam episodic frames (menekankan pada satu masalah saja) atau thematic frames (muncul dari konteks social dan politik yang lebih luas). Iyengar menyimpulkan dari penelitiannya bahwa audiens cenderung lebih mudah menerima pesan dalam episodic frames karena lebih detail dan sempit dalam bingkai beritanya dibanding thematic frames (R. V. L. V. Zoonen, 2011).

Sejumlah ilmuwan komunikasi politik melihat adanya efek pada repetitive framing dan competitive framing. Mereka 
berpendapat bahwa berita yang dimuat berulang-ulang (repetitive framing) akan meningkatkan derajat aksesibilitasnya, yang pada akhirnya akan menguatkan framing pesan dalam berita tersebut (Dennis Chong, 2007b). Sedangkan competitive framing terjadi ketika ada dua berita yang saling bertentangan berkembang pada waktu yang sama. Hal ini akan membawa dampak meningkatnya nilai individu audiens dan menurunkan efek pemberitaannya. Hal ini terjadi karena ketika dihadapkan pada dua berita yang bertentangan satu sama lain, audiens akan merujuk pada tokohtokoh masyarakat yang dia percaya atau kembali pada nilai, pengetahuan dan pengalaman yang telah dimiliki sebelumnya (Vreese, 2012).

Beberapa penelitian efek framing di atas cenderung melihat audiens sebagai audiens pasif yang hanya 'bereaksi' ketika diterpa media. Hal ini wajar terjadi, karena sebagaimana halnya penelitian efek media lainnya, titik berat perhatian berada pada media teks dan reaksi audiens terhadap media teks tersebut. Padahal sebenarnya audiens memiliki otoritasnya sendiri dalam memaknai isi media; apakah dia akan menerima secara utuh, hanya sebagian atau tidak percaya sama sekali dengan isi media. Apalagi dalam perkembangan teknologi komunikasi saat ini, di mana setiap orang bisa mengakses berita dari mana saja dan kapan saja. Setiap orang juga bisa menjadi konsumen sekaligus produsen dari berita itu sendiri. Oleh sebab itu tidaklah tepat jika audiens hanya dipandang sebagai pihak yang pasif, tidak berbuat apa-apa dalam menerima isi media.

Berkaitan dengan perkembangan new media serta teknologi komunikasi saat ini, maka sudah seharusnya penelitian framing dilihat secara lebih komprehensif. Penelitian tentang framing media tidak bisa lagi dilihat terpisah tanpa melibatkan audiens, karena di tengah berkembangnya media sosial saat ini setiap orang bisa memproduksi dan mereproduksi berita. Kajian audiens framing juga perlu dikembangkan untuk mendapatkan hasil yang lebih terintegrasi terkait suatu isu jika dilihat dari dua sisi: media framing dan audience framing.

\section{Audience Framing}

Seperti telah dijelaskan diatas, kajian tentang audience framing berawal dari kajian efek media framing. Etman (1991) menyebutnya sebagai individual frames', yaitu proses mental seseorang dalam mengolah informasi yang dia dapat setelah mengkonsumsi media frames. Audiens framing memang tidak bisa dipisahkan dari teori Hall (1980) mengenai encoding/decoding. Media meencode realitas menjadi pesan dalam media teks, kemudian audiens men-decode pesan itu sesuai dengan pengetahuan, nilai, kepercayaan dan pengalamannya. Oleh sebab itulah suatu pesan di media bisa dimaknai berbeda oleh masing-masing individu atau disebut dengan polysemi.

Adanya perbedaan pemaknaan di benak audiens terhadap isi teks media ini sebenarnya telah lama disadari, terutama dalam proses konstruksi sosial di tengah masyarakat. Gamson (1988) berpendapat, bahwa konstruksi sosial di tengah masyarakat terbentuk dari proses interaksi sosial di antara mereka. Dalam proses ini, aktivitas audiens dalam menginterpretasi teks media menjadi dasar dari pembentukan opini publik di tengah masyarakat. Hal ini bertentangan dengan kesimpulan Iyengar (1991) yang memfokuskan pada reaksi audiens terhadap framing media, dalam konstruksi sosial lebih menekankan pada proses 
berfikir dan berinteraksi individu dalam memaknai suatu isu (Sotirovic, 2000).

Seperti telah disinggung di muka, bahwa perkembangan teknologi komunikasi dewasa ini membawa konsekuensi terjadinya perubahan signifikan terhadap teori-teori komunikasi, khususnya pada hal yang berkaitan dengan studi audiens. Terkait hal ini, Maxwell McCombs mencoba me-review kembali teori Agenda Setting yang telah banyak dibahas dan digunakan oleh para ilmuwan media dan komunikasi sejak pertama dikenalkan pada tahun 1972. Menurut McCombs, perkembangan teknologi komunikasi khususnya internet telah membawa perubahan yang signifikan khususnya dalam proses pembentukan agenda media dan agenda publik, dua bahasan utama dalam penelitian agenda setting (McCombs, 1972).

Tinjauan penelitian agenda-setting oleh McCombs ini menarik karena dia menyadari bahwa perubahan teknologi komunikasi telah berubah sama sekali jika dibanding 40 tahun lalu ketika teori agenda-setting pertama kali diluncurkan bersama DonaldShawn. Dalamtulisannya yang berjudul 'A Look at Agenda-Setting: Past, Present and Future', McCombs mencoba mengidentifikasi beberapa perubahan mendasar dari perubahan situasi tersebut dan memformulasikan ulang konsep agenda-setting menjadi second level agenda-setting atau agenda setting level kedua (McCombs, 2005). Dalam tinjauannya ini McCombs melihat bahwa proses second level agenda-setting ini sebenarnya beririsan dengan proses framing, di mana agenda media tidak hanya terbatas pada penyampaian informasi tentang suatu fakta saja, melainkan atribusi dari suatu peristiwa yang disampaikan melalui agenda media. Atribusi fakta atau peristiwa ini sama dengan media frames. Sedangkan agenda publik adalah bagaimana publik menginterpretasi isu yang ia dapatkan dari beragam media informasi baik surat kabar, televisi, radio, maupun mediamedia online lainnya.

Beragamnya media yang menjadi sumber referensi publik terhadap suatu inilah yang menjadi tolok ukur perubahan konsep agenda-setting tradisional - yang sudah kita kenal sebelumnya - dengan second level agenda-setting yang baru. Setidaknya ada dua hipótesis McCombs terkait perubahan ini dan membuatnya memformulasikan ulang teori agendasetting-nya. Hipotesis tersebut adalah: pertama, kemampuan audiens mengakses internet, baik itu website maupun blog untuk mencari informasi atau hanya memberi komentar. ${ }^{1}$ Hipotesis kedua adalah banyaknya agenda media yang bisa diakses publik melalui websites dengan beragam versinya, tidak seperti pengulangan agenda yang biasanya ada pada media tradisional.

Minimal ada dua hipotesis yang menjadi perhatian McCombs terkait hipótesis pertamanya yaitu kemampuan publik mengakses internet, karena dibutuhkan penguasaan teknologi dan ketersediaan komputerataualatlain untuk mengaksesnya. Dalam perkembangan teknologi yang semakin terjangkau saat ini, tampaknya hal tersebut tidak lagi menjadi masalah, hanya saja publik yang mengakses internet adalah mereka dengan latar pendidikan yang lebih baik dan berasal dari kalangan muda. Selain itu, McCombs juga melihat kebiasaan publik dalam mengakses media yang jauh berbeda dengan media tradicional. Jika

${ }^{1}$ Artikel ini ditulis pada tahun 2005, dimana media sosial belum muncul dan menjadi mainstream di dunia maya. 
pada media tradisional mereka memiliki waktu-waktu tertentu untuk membaca surat kabar atau menonton acara televisi, hal ini tidak berlaku pada media baru, karena mereka bisa mengakses internet di mana saja dan kapan saja.

Hipótesiskedua dari McCombadalah banyaknya informasi yang bisa diakses melalui websites, di mana kenyataan ini kebalikan dengan tradisional media yang memiliki keterbatasan tempat dan waktu untuk menayangkan suatu isu, sehingga media tradisional ini cenderung memuat suatu isu secara berulang untuk mendapatkan perhatian dari audiensnya. Oleh sebab itu, perbedaan kajian agenda setting yang lama dengan yang baru terletak pada beragamnya sumber media yang bisa diakses oleh audiens. Hal ini menyebabkan tidak mudah untuk menentukan agenda media dalam penelitian agenda setting jika menggunakan teori yang lama.

Oleh sebab itu McCombs mencoba 'merevisi' tinjauan teori agenda-setting klasik miliknya menjadi second level agenda-setting theory. Secara umum teori agenda-setting ini tidak berubah, yaitu adanya 'perpindahan' agenda media kepada agenda publik. Namun demikian, mengingat adanya perubahan lingkungan masyarakat dan teknologi media yang berkembang, maka ada penyesuaian 'cara' melihat agenda media dan agenda publik ini. Jika agenda media dipahami sebagai topik yang diangkat oleh media tradisional pada agenda setting klasik, pada second level agenda setting, agenda media lebih dipahami sebagai media frames, atau atribusi pesan yang sengaja ditonjolkan dari sebuah isu. Hal ini dilakukan mengingat begitu banyaknya sumbersumber informasi berkenaan dengan isu terntentu, meskipun demikian McCombs melihat adanya perhatian yang terpusat pada beberapa fakta saja dari suatu isu. Sehingga McCombs memutuskan bahwa terjadi atribusi isu, tidak hanya menyampaikan informasi umum dari suatu fakta; namun juga menonjolkan bagian-bagian tertentu dari fakta (framing) tersebut untuk mendapatkan perhatian lebih. Demikian pula yang terjadi pada publik, jika pada teori klasik disebut 'agenda publik' yang melihat tema atau topik apa menjadi perhatian publik terhadap suatu isu, pada second level agenda setting disebut dengan 'agenda setting effects' atau efek agenda setting yang melihat bagaimana publik mengintepretasi suatu isu, bagian mana dari isu tersebut yang menjadi perhatian (salience) dari audiens (McCombs, 2005).

Proses yang terjadi pada agenda setting effects sejalan dengan proses terbentuknya audience framing, yaitu proses intepretasi framing media oleh audiens menurut pengetahuan, pengalaman dan interaksi dengan lingkungan sosialnya. Ada beberapa pendekatan dalam melihat audience framing ini, di antaranya melalui resource strategies (Gamson, 1992) dan need for orientation (McCombs, 2005). Resource strategies atau strategi rujukan adalah strategi audiens dalam menggunakan rujukan untuk menginterpretasi bingkai media. Menurut Gamson, strategi rujukan ini terbagi menjadi dua, yaitu substantial media effects strategy dan personal strategy. Strategi pertama adalah mereka yang menggunakan strategi budaya, popular wisdom, kebenaran umum, bahkan stereotype dan nilai-nilai umum yang telah jamak dipahami secara luas. Orangorang yang menggunakan strategi ini cenderung mudah terpengaruh oleh media frames. Sedangkan strategi kedua dilakukan oleh mereka yang lebih mengutamakan pada pengalaman langsung maupun tidak langsung dengan 
media frames, sehingga audiens dengan strategi ini cenderung tidak mudah terpengaruh dengan isi media.

Di sisi lain McCombs (2005) melihat need for orientation atau orientasi kebutuhan audiens ketika mereka mengkonsumsi isi media karena pada dasarnya setiap manusia itu memiliki rasa ingin tahu yang besar. Oleh sebab itu orientasi kebutuhan audiens ketika mengkonsumsi media ditentukan oleh dua konsep yaitu relevansi (relevance) dan ketidakpastian (uncertainty). Orientasi kebutuhan seseorang disebut rendah ketika melihat suatu isu memiliki derajat relevansi dan ketidakpastian yang rendah terhadap dirinya. Jika derajat relevansinya tinggi namun ketidakpastiannya rendah, maka orientasi kebutuhan orang tersebut adalah menengah atau moderate. Sedangkan jika suatu isu memiliki derajat relevansi dan ketidakpastian yang tinggi maka orientasi kebutuhan orang tersebut terhadap suatu isu menjadi tinggi juga.

Selain relevansi dan ketidakpastian, McCombs menambahkan komponen ketiga dari orientasi kebutuhan ini yaitu derajat usaha untuk mengakses media. Hal ini berdasarkan temuan Gunho Lee (2005) terkait upaya seseorang untuk mendapatkan informasi melalui dunia maya. Tidak seperti media tradisional (TV, Radio, Surat Kabar) yang informasinya telah tersaji dan mudah diakses oleh audiens, pada media baru seperti internet, audiens harus berusaha terlebih dahulu untuk bisa mendapatkan informasi yang diinginkan (McCombs, 2005).

Chong dan Druckman (2007) menetapkan tiga langkah dalam mekanisme psikologis audiens dalam proses efek framing (Dennis Chong, 2007a). Pertama, audiens sebelumnya telah memiliki pengetahuan dan kepercayaan didalam memori otaknya. Kemudian langkah kedua adalah beberapa kepercayaan tersebut berada ditempat yang mudah diakses ketika audiens menangkap isu yang telah diframing oleh media, sehingga ia akan 'mencocokkan' apakah pengetahuan dan kepercayaan yang dia miliki sesuai dengan isu media yang dia dapatkan. Terakhir audiens akan mengevaluasi isu tersebut dan mempertimbangkan apakah perlu untuk dibingkai atau tidak. Dua faktor yang akan mempengaruhi audiens ketika ia mempertimbangkan suatu isu untuk diframe atau tidak, yaitu motivasi individu dan konteks kompetitif dari isu tersebut (Chong, 2007a; Lecheler, 2009). Motivasi individu berkaitan dengan penting tidaknya isu tersebut terhadap dirinya, sedangkan konteks kompetitif adalah keberadaan framing isu yang bertentangan yang mungkin mempengaruhi apakah isu tersebut makin menguat dibenak audiens, atau membuat audiens frame baru.

Dalam penjelasan di atas tampak bahwa proses audience framing sejalan dengan second level agenda-setting theory, dengan lebih memperhatikan perkembangan teknologi komunikasi di masa kini. Saat ini penelitian tentang mediaaudiens sudah tidak bisa dilihat sebagai interaksi tunggal, yang berlaku satu isu dari satu media kemudian memberikan efek terhadap audiens, melainkan melihat interaksi media-audiens dengan perspektif yang baru.

\section{Audience Framing : Beberapa Isu Metodologi}

Pertanyaan berikut terkait audiens framing adalah bagaimana metodologi penelitiannya? beberapa penelitian mengenai efek media framing dan audiensce framing telah dilakukan oleh para ilmuwan komunikasi khususnya dalam 
bidang komunikasi politik dan opini publik. Pemetaan penelitian efek framing telah dibuat jelas oleh Dietram Scheufele (1999) dalam artikelnya 'Framing as a Theory of Media Effects'. Dalam artikel ini Scheufele tidak hanya memetakan pendekatan penelitian framing, tapi juga proses terbentuknya framing media hingga audiens framing (Scheufele, 1999).

Pemetaan pendekatan penelitian framing menurut Scheufele (1999) bisa dilihat dari dua dimensi : pertama dari tipe frame yang diteliti (media frames atau audience frames) dan bagaimana operasionalisasi frame-frame tersebut ke dalam kerangka penelitian, apakah sebagai dependent variabel atau independenvariabel (Scheufele, 1999). Framing sebagai dependenvariabeladalahstudiyangmeneliti beragam faktor yang mempengaruhi proses modifikasi terbentuknya Misalnya penelitian Schoemaker \& Reese (1996) yang meneliti tentang media frame oleh jurnalis dipengaruhi oleh faktor-faktor sosial-budaya dan kebijakan organisasi. Sedangkan individual frame dipengaruhi oleh ideologi yang dimilikinya (Tuchman, 1978), atau audience frame yang langsung dipengaruhi oleh bagaimana media membingkai suatu isu (Prince, Tewksbury \& Power, 1995, 1995) (Scheufele, 1999).

Selanjutnya penelitian framing sebagai variabel independen terletak pada hubungan media-audiens dalam proses framing, bagaimana media frames sebagai independen variabel mempengaruhi audience frame dan begitu pula sebaliknya. Beberapa penelitian tentang media frames sebagai independen variabel misalnya penelitian yang dilakukan oleh Pan \& Kosicki (1993) yang menggambarkan struktur wacana media ke dalam empat struktur: sintaksis, skrip, tematik dan retorikal. Dari keempat stuktur ini bisa diketahui pengaruh teks media terhadap proses terbentuknya media teks. Sebaliknya, penelitian individual frame sebagai independen variabel fokus pada frame individu mempengaruhi gerakan sosial di masyarakat. Seperti temuan Gamson (1985) yang meneliti pengaruh frame individu dalam menginterpretasi konflik terhadap tindakan kolektif yang mengarah pada gerakan sosial.

Selain memetakan media frame dan audience frame pada variabel independen dan dependen, Scheufele juga mencoba membuat model framing agar tampak dimana posisi audience framing dan efeknya. Scheufele menggambarkan proses framing kedalam beberapa tahap, yaitu: frame building, frame setting, individual-level effects of framing dan link yang menghubungkan antara audiens dan jurnalis. Kedudukan masing-masing proses tersebut bisa dilihat pada gambar 1 .

Pada proses pembentukan frame media (frame building) ada beberapa faktor yang mempengaruhinya, yaitu kebijakan media, nilai, sikap dan ideologi dari jurnalis, juga tekanan-tekanan dari lingkungan sosial dan politik di sekitar media tersebut. Shoemaker \& Reese (1996) mengatakan bahwa paling tidak ada tiga sumber yang mempengaruhi terbentuknya frame media ini (Reese, 1996). Pengaruh pertama adalah dari jurnalis sebagai pelaku utama pembuat frame media, seperti ideologi yang dimiliki jurnalis, sikap jurnalis terhadap suatu isu, juga nilai-nilai profesional yang dipercaya oleh jurnalis. Sumber kedua adalah proses rutin seleksi atau 'gate keeping' dalam ruang redaksi, dimana kebijakan organisasi juga sangat mempengaruhi arah frame media terhadap suatu isu. Ketiga adalah sumber yang berasal dari luar organisasi media seperti elit politik, pihak penguasa, dan juga kelompok kepentingan lainnya. 


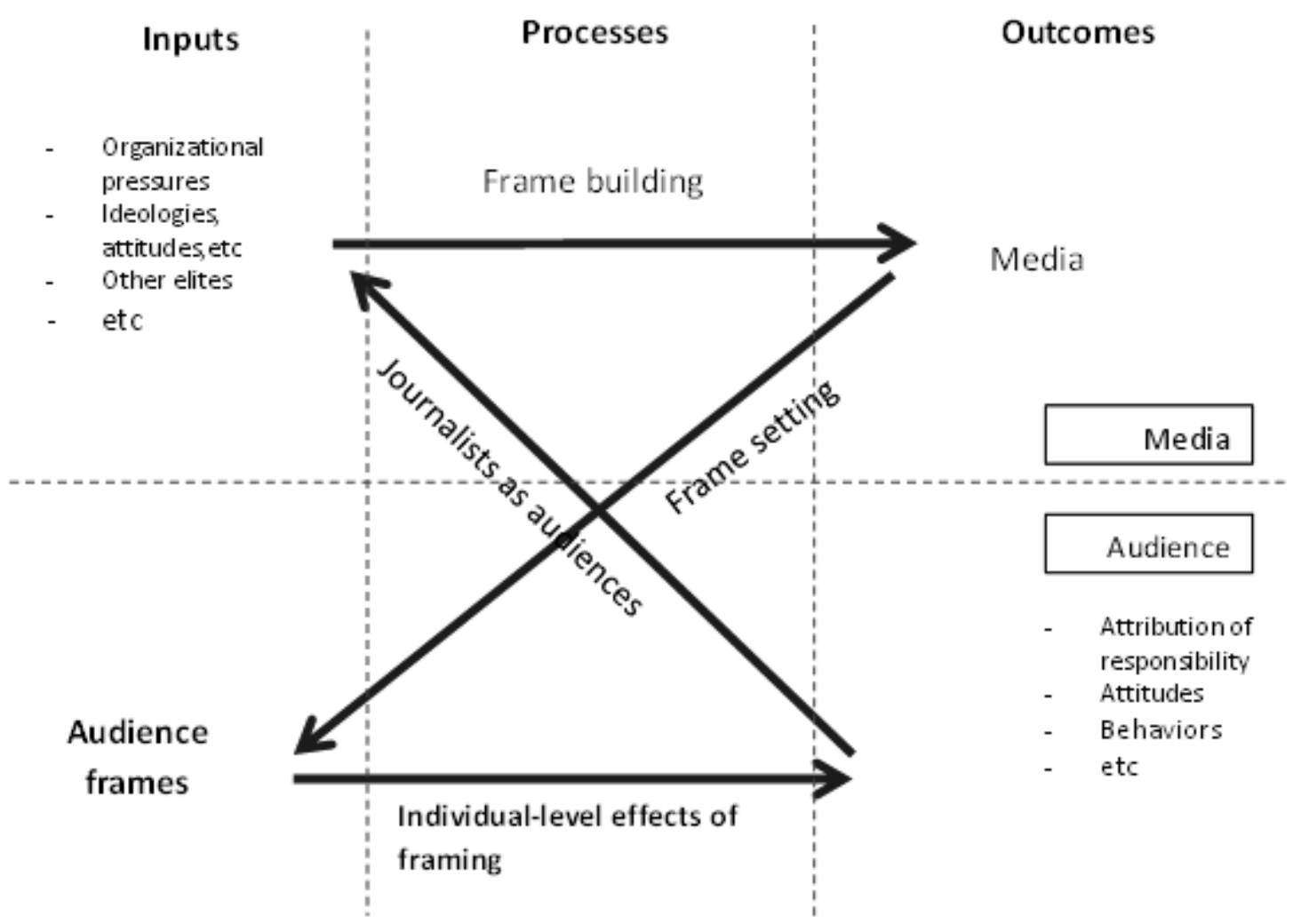

Gambar 1. Model proses dari penelitian Framing oleh Dietram Scheufele (1999)

Proses kedua adalah frame setting, di mana menurut Scheufele sama dengan proses second level agenda setting dari McCombs, yaitu proses transmisi media frame ke audience frame. Frame media yang muncul dalam agenda media bisa dilihat dari dua dimensi, yaitu visibilitas atau kemampuannya menarik perhatian dan kepentingan audiens serta valence atau derajat keterkaitan isu media dengan kepentingan audiens. Sedangkan jika dilihat dari audience frames, suatu isu dianggap menarik jika memenuhi dua kriteria, yaitu social salience atau merupakan hal menarik oleh masyarakat sosial dan personal salience atau hal yang menarik bagi individu (McCombs, 2005).

Dari sisi audiens, ada beberapa faktor yang mempengaruhi terbentuknya audience framing, yang oleh Gamson (1992) diidentifikasi menjadi tiga yaitu: kultural, personal dan integrated. Pendekatan kultural biasanya digunakan untuk membangun frame individu yang umum berada ditengah masyarakat, berdasarkan wacana dan popular wisdom yang ada. Pendekatan personal berdasarkan pengalaman pribadi dan norma moral yang biasa berlaku, namun tidak melibatkan wacana media. Sedangkan pendekatan integratif adalah integrasi antara wacana media, popular wisdom dan pengalaman pribadi dalam pembentukan frame individu dalam diskusi (Gamson, 1992).

Setelah media frames ditransfer ke audience frame, selanjutnya Scheufele menjelaskan tahap berikutnya dalam 
proses framing, yaitu efek individual dalam proses audience framing. Efek yang ditunjukkan meliputi kognisi atau pengetahuan, sikap dan perilaku individu yang berubah setelah dipengaruhi oleh media frames dan audience frame. Sebagai contoh studi yang dilakukan oleh Iyengar (1991) menunjukkan bahwa episodic frame, atau frame isu yang terbatas pada satu fakta atau pelaku saja, memberikan pemahaman yang lebih baik kepada audiens dibanding dengan frame tematik yang lebih abstrak.

Terakhir adalah proses yang menghubungkan antara audiens dengan jurnalis sebagai pelaku pembuat media frames. Sebagai bagian dari masyarakat, tidak bisa dipungkiri bahwa jurnalis juga menjadi bagian dari audiens. Oleh sebab itu audies juga memiliki peluang yang besar untuk mempengaruhi media frames, khususnya terkait dengan isuisu terkini yang sering menjadi wacara publik di luar media.

Secara garis besar, penelitian-penelitian seputar audiens framing berusaha menelusuri beragam faktor yang mempengaruhi terbentuknya audience framing; baik itu faktor yang berasal dari media, bentuk teks, cara menyampaikannya, maupun faktor terkait dengan individu seperti nilai personal, pengaruh kelompok rujukan dan tingkat relevansi isu dengan kepentingannya. Contoh penelitian yang mencoba melihat perbedaan cara mengekspos berita dan personal values adalah penelitian yang dilakukan oleh Lin (2009). Lin meneliti ekspos berita perang Iraq melalui beragam media dan program yang berbeda ${ }^{2}$ beserta

\footnotetext{
2 Sumber media framing yang diteliti adalah
}

pengaruhnya terhadap pembentukan frame audiens dengan perbedaan latar belakang jiwa nasionalisme \& patriotik, agama dan politik. ${ }^{3}$ Dari penelitian ini Lin menyimpulkan bahwa opini publik (dan audience frames) bisa terbentuk dari interaksi antara cara media mengekspos berita dan nilai-nilai individual.

Huiping Huang (2009) yang melihat perbedaan frame media dalam proses terbentuknya audiens frames. Studi ini meneliti perbedaan liputan tiga media besar di Taiwan mengenai dua isu kontroversial yang muncul bersamaan, sedangkan audiens frames didapat dari interview melalui telepon secara acak. Análisis dari penelitian ini dilakukan dalam dua tahap; pertama membandingkan media frames dan audience frames, dan melihat seberapa jauh media mempengaruhi terbentuknya audiens frames. Tahap análisis kedua adalah melihat faktor-faktor yang paling mempengaruhi individu dalam membuat audience framing. Temuan Huang yang menarik adalah media frame dari suatu isu yang muncul bervariasi di media akan menghasilkan audience frame yang beragam pula, sebaliknya, jika suatu isu cenderung diframing sama oleh media maka audiens juga cenderung memiliki frames yang seragam pula terhadap isu tersebut (Huang, 2009).

program dan media yang menayangkan pemberitaan invasi Amerika ke Iraq pada tahun 2003. Lin mengkategorikannya menjadi : program talkshow di TV kabel, program berita di TV Kabel, program talkshow di radio dan siaran berita di TV umum.

3 Responden ditanya dalam skala 1-7 apakah mereka memiliki jiwa nasionalisme \& patriotic membela Negara, sebagai individu yang religious, dan berpandangan politik sangat konservatif atau sangat liberal. 
Penelitian mengenai audience framing tidak hanya terbatas pada reaksi terhadap media frames dan menggunakan metode survey. Penelitian yang dilakukan oleh Prince dkk (2005) adalah salah satu penelitian menarik yang memperkaya varian metodologi audience framing, yaitu dengan mem-framing diskusi publik dengan menggunakan metode eksperimen. Prince dkk mencoba menginvestigasi frame publik (di AS) - yang dikelompokkan menjadi tiga, yaitu yang memiliki pandangan politik konservatif, liberal dan campuran keduanya - mengenai isu kesetaraan hak bagi kaum homoseks di tengah masyarakat (Vincent Prince, 2005). Hasil menarik dari penelitian ini adalah adanya perbedaan pemberian 'label' pada para penyuka sejenis, yaitu bagi kelompok konservatif menyebut 'homosexual' sedangkan kelompok liberal lebih suka menyebut 'gay'. Penelitian ini juga memperkuat pendapat Gamson (1992) bahwa media frames itu hanyalah bagian dari 'alat' untuk membentuk audience frames, karena penelitian membuktikan bahwa mereka yang telah memiliki ideologi pemikiran sendiri tidak terlalu terpengaruh oleh pemberitaan di media.

Beberapa contoh penelitian di atas menunjukkan bahwa peluang penelitian audience framing masih terbuka lebar, dan beragam variasinya. Sebagian besar penelitian framing adalah menginvestigasi pengaruh media framing terhadap terbentuknya opini publik atau audiens framing. Sedangkan proses sebaliknya dimana audience frames mempengaruhi media frames - masih jarang dilakukan. Padahal, audiens memiliki power dan otoritas untuk mengakses, menseleksi dan memaknai isi berita yang dia dapat. Penelitian yang dilakukan oleh Prince dkk menunjukkan peran aktif audiens tersebut, meskipun tidak secara langsung menyinggung tentang media frames yang muncul seputar isu tersebut.

\section{Peluang Penelitian Audience Framing di Indonesia}

Bagaimana dengan peluang penelitian audience framing di Indonesia? Indonesia memiliki masyarakat dengan beragam etnis, ideologi, agama, hingga perbedaan latar belakang sosial-ekonomi dan penguasaan teknologi. Di samping memiliki variasi kombinasi audiens yang cukup besar, penduduk Indonesia juga menempati angka terbesar keempat di dunia. Hal ini berarti masih terbuka peluang yang sangat besar untuk mengeksplorasi topik kajian ini secara lebih mendalam.

Ada beberapa hal mendasar yang harus dipertimbangkan ketika akan mendesain penelitian audience framing di Indonesia khususnya dalm kondisi masyarakat yang multi etnis. Beberapa pertimbangan tersebut diantaranya: posisi audiens, faktor budaya dan pengusaan teknologi media. Posisi audiens terkait dengan sudut pandang audiens dilihat sebagai audiens pasif atau aktif. Dalam penelitian-penelitian opini publik, audience framing dilihat sebagai efek dari media frames. Seperti halnya apa yang dilakukan oleh Huang (2009) di atas, yang melihat framing audiens tentang dua isu Taiwan yang dimuat di media. Di sisi lain, audiens memiliki peran aktif dalam penelitian audience framing ketika akan melihat faktor-faktor yang mempengaruhi terbentuknya 
audience framing, atau ingin mengetahui tanggapan audiens terhadap suatu isu terlepas dari pengaruh media semata.

Sebagai masyarakat yang multi etnis, pertimbangan faktor-faktor budaya menjadi sangat penting dalam penelitian audience framing. Menurut Hofstede (1986) dalam konsep cultural variabilities, tipologi masyarakat Indonesia tergolong masyarakat kolektivis. Masyarakat kolektivis adalah masyarakat yang berkelompok, dan setiap individu di dalamnya terikat dengan kelompoknya (Hofstede, 1986). Kelompok yang dimaksud bisa dalam artian keluarga, organisasi, atau kelompok agama. Meskipun dalam kehidupan saat ini nilai-nilai global semakin tersebar karena didukung oleh pesatnya teknologi komunikasi di perkotaan, ada asumsi bahwa masyakarat di kota-kota besar Indonesia cenderung individualis. Namun demikian belum ada data empiris yang menyatakan asumsi tersebut.

Dalam masyarakat kolektivis, nilainilai dalam kelompok ini dijunjung tinggi dan menjadi rujukan dalam menilai dunia termasuk memframing berita. Sebagai contoh pengaruh nilai-nilai agama khususnya Islam dalam pemberitaan media. Kasus pelarangan konser Lady Gaga tahun 2012 dan pelarangan terbitnya majalah Playboy Indonesia tahun 2007 lalu terjadi karena adanya tekanan keras kelompok-kelompok umat Islam melalui demonstrasi yang massif di beberapa kota di Indonesia. Oleh sebab itu memasukkan kelompok rujukan sebagai salah satu faktor penting yang mempengaruhi proses terbentuknya audiens frames di Indonesia.
Selain penetapan peran audiens dan faktor budaya dalam penelitian audience framing di Indonesia, satu hal penting yang juga perlu dipertimbangkan adalah penggunaan teknologi komunikasi dalam mengakses media. Perkembangan teknologi komunikasi ini mendorong semakin luasnya penggunaan new media termasuk social media yang membawa perubahan signifikan dalam kajian-kajian komunikasi dewasa ini. McCombs (2005) dalam teori secondary agenda-setting-nya juga telah mempertimbangkan faktor effortness atau usaha audiens dalam mencari informasi dalam internet. Dalam konteks Indonesia, jumlah pengguna teknologi komunikasi atau sering disebut gadget dalam bentuk Smart pone,notebook, laptop, dan perangkat canggih lainnya semakin meningkat khususnya di daerah perkotaan.Hasil riset yang dilakukan oleh MarkPlus Insight Indonesia pada tahun 2011 menyatakan bahwa pada tahun 2011 pengguna internet di 11 kota besar Indonesia mencapai 55 juta pengguna atau sekitar $40-45 \%$ dari total penduduk di kota-kota tersebut (Wahono, 2011). Hasil penelitian ini juga menyatakan bahwa jumlah mobile internet user atau pengguna internet dari perangkat mobile seperti Smartphone dan notebookdi Indonesia pada tahun tersebut mencapai 29 juta, naik hampir 100\% dari tahun sebelumnya yang hanya berkisar 16 juta pengguna dan $50-80 \%$ usia penggunanya berkisar antara 15-30 tahun. Ini berarti bahwa pertimbangan pengguna gadget ini menjadi penting ketika desain riset audience framing bertujuan meneliti target audiens kalangan usia tersebut, karena berarti sebagian besar dari mereka adalah pengguna mobile internet. 
Beberapa pertimbangan di atas kemudian bisa dimodifikasi dengan isu tertentu untuk menghasilkan beragam variasi desain riset audience framing di Indonesia. Perubahan teknologi komunikasi termasuk makin berkembangnya new media yang lebih interaktif dalam sosial media misalnya, semakin memperkaya unit análisis audience framing ini di masa depan. Perubahan ini juga membawa dampak berkembangnya kajian teori-teori audiens seperti cultivation theory, uses $\mathcal{E}$ gratifications dan reception theory yang menganalisis relasi one to one antara media dan audiens. Dalam kajian audience framing, relasi ini diperluas karena perkembangan teknologi media menyebabkan tidak mungkin lagi dibatasi sumber media teks hanya dari satu media saja yang membawa efek pada terbentuknya audience framing.

\section{Simpulan}

Studi mengenai audience framing pada dasarnya bukanlah kajian baru dalam studi ilmu komunikasi. Studi audience framing ini berasal dari integrasi teori framing dan teori-teori audiens. Pada awalnya teori framing ini lebih banyak menganalisis proses terjadinya frame di media dan kemudian berkembang pada efek yang ditimbulkan media framing terhadap audiens. Pada masa ini audiens memang lebih banyak diperlakukan sebagai passive audience. Namun dalam perkembangan selanjutnya, kajiankajian tentang faktor-faktor yang mempengaruhi proses penerimaan terhadap teks media dan terbentuknya frame audiens menempatkan audiens pada posisi active.
Dalam konteks Indonesia yang multi etnis, peluang pengembangan penelitian audience framing masih terbuka lebar. Beragam variasi desain riset audience framing bisa dibuat dengan mengkombinasikan peran audiens, pengaruh budaya dan penggunaan teknologi komunikasi. Semoga dengan mengimplementasikan audiens framing ini akan menambah khasanah pengetahuan mengenai masyarakat Indonesia khususnya dalam ranah kajian audiens dalam ilmu komunikasi.

\section{Daftar Pustaka}

David A SnowE Burke Rochford, S. K. W., Robert D Benford (1986). Frame Alignment Process, Micromobilization and Movement Participation. American Sociology Review, 51(4 (Aug)), 464-481.

Dennis Chong, J. N. D. (2007a). Framing Theory. Annual Review Political Science, 10, 103-126.

Dennis Chong, J. N. D. (2007b). A theory of Framing and Opinion Formation in Competitive Elite Environment. Journal of Communication, 57, 99-118.

Druckman, J. N. (2001). On the Limits of FramingEffects: Who Can Frame? The Journal of Politics, 63(4, November 2001), 1041-1066.

Entman, R. M. (1993). Framing : Toward Clarification of a Fractured Paradigm. Journal of Communication, 43(4). 
Gamson, W. A. (1992). Talking Politics. Cambridge England: Cambridge University Press.

Gillespie, M. (2005). Media Audiences. Bekshire, England: Open University.

Gitlin, T. (1980). The whole world is Watching: Mass Media in the Making and Unmaking of the New Left. Berkeley: University of California Press.

Hall, S. (1980). Encoding/Decoding. In D. H. S Hall, A. Love \& P. Wilis (Ed.), Culture, Media, Language: Working Papers in Cultural Studies (pp. 128138). London: Hutchinson.

Hofstede, G. (1986). Cultural Differences in Teaching and Learning. International Journal of Intercultural Relations, 10, 301-320.

Kitzinger, J. (2007). Framing and Frame Analysis. In E. Devereux (Ed.), Media Studies Key Issues and Debate (1 ed., Vol. 1). London: Sage Publications.

Klapper, J. (1960). The Effects of Mass Communication. New York: Free Publisher.

Kosicki, Z. P. G. M. (1993). Framing Analysis: An Approach to News Discourse. Political Communication, 10, 55-75.

Maxwell McCombs, D. S. (1972). The Agenda Setting Function of Mass Media. Public Opinion Quarterly, 36(2), 176-187.

McCombs, M. (2005). A Look at AgendaSetting: past, present and future. Journalism Studies, 6(4), 543-557.

McQuail, D. (1994). Mass Communication Theory : An Introduction (3rd ed.).
California: Thousand Oak CA Sage.

Nightingale, V. (2004). Contemporary Television Audience s Publics, Markets, Communities and Fans. In J. D. Downing (Ed.), The Sage Handbook of Media Studies (Vol. 1). California: Sage Publication Inc.

Reese, P. J. S. S. D. (1996). Mediating the Message. white Plains, NY: Longman.

Scheufele, D. A. (1999). Framing as a Theory of Media Effects. Journal of Communication, 49(1), 103-122.

Sophie Lecheler, C. d. V. a. R. S. (2009). Issue Importance as a Moderator of Framing Effects. Communication Research, 36(3), 400-425.

Sotirovic, M. (2000). Effects of Media Use on Audience Framing and Support for Welfare. Mass Communication and Society, 3(2\&3), 269-296.

Sullivan, J. L. (2013). Media Audience s Effects, Users, Institutions and Power. California: Sage Publication Inc.

Tuchman, G. (1978). Making News: A Study in the Construction of Reality. New York: Free Press.

Vincent Prince, L. N., Joseph N Capella. (2005). Framing Public Discussion of Gay Civil Unions. Public Opinion Quarterly, 69(2), 179-212.

Vreese, C. H. d. (2012). New Avenues for Framing Research. American Behavioral Scientist, 56(3), 365-375.

Wahono, T. (2011, 28 Oktober 2011). Naik 13 Juta, Pengguna Internet Indonesia 55 juta orang Retrieved 9 April, 2013

Webster, J. G. (1998). The Audience . Journal of Broadcasting and Electronic 
Media, 42(2), 190-207.

Zoonen, R. V. L. V. (2011). Power to Frame : Bringing Sociology Back to Frame Analysis. European Journal of Communication, 26(2), 101-115.
Zoonen, V. (1992). The Women's Movement and the Media: Constructiong a Public Identity. European Journal of Communication, 7(4), 453 - 476. 